\title{
A Serological Survey of Ruminant Livestock in Kazakhstan During Post-Soviet Transitions in Farming and Disease Control
}

\author{
By M. Lundervold ${ }^{1}$, E.J. Milner-Gulland ${ }^{2}$, C.J. O'Callaghan ${ }^{3}$, C. Hamblin ${ }^{4}$, A. Corteyn ${ }^{4}$ and \\ A.P. Macmillan ${ }^{5}$
}

${ }^{1}$ Ecology and Epidemiology Group, Department of Biological Sciences, University of Warwick, Coventry, ${ }^{2}$ Department of Environmental Science and Technology, Imperial College, London, ${ }^{3}$ Department of Community Health and Epidemiology, Queen's University, Kingston, Ontario, Canada, ${ }^{4}$ Institute for Animal Health, Pirbright Laboratory Ash Road, Pirbright, Woking Surrey, and ${ }^{5}$ Central Veterinary Laboratory, Veterinary Laboratories Agency, Addlestone, Surrey.

\begin{abstract}
Lundervold M, Milner-Gulland EJ, O'Callaghan CJ, Hamblin C, Corteyn A, Macmillan AP: A serological survey of ruminant livestock in Kazakhstan during post-Soviet transitions in farming and disease control. Acta. Vet. Scand. 2004, 45, 211-224. - The results of a serological survey of livestock in Kazakhstan, carried out in 1997-1998, are reported. Serum samples from 958 animals (cattle, sheep and goats) were tested for antibodies to foot and mouth disease (FMD), bluetongue (BT), epizootic haemorrhagic disease (EHD), rinderpest (RP) and peste des petits ruminants (PPR) viruses, and to Brucella spp. We also investigated the vaccination status of livestock and related this to changes in veterinary provision since independence in 1991. For the 2 diseases under official surveillance (FMD and brucellosis) our results were similar to official data, although we found significantly higher brucellosis levels in 2 districts and widespread ignorance about FMD vaccination status. The seroprevalence for BT virus was $23 \%$, and seropositive animals were widespread suggesting endemicity, despite the disease not having being previously reported. We found a few seropositives for EHDV and PPRV, which may suggest that these diseases are also present in Kazakhstan. An hierarchical model showed that seroprevalence to FMD and BT viruses were clustered at the farm/village level, rather than at a larger spatial scale. This was unexpected for FMD, which is subject to vaccination policies which vary at the raion (county) level.
\end{abstract}

seroprevalence; bluetongue; EHD; PPR; FMD; brucellosis.

\section{Introduction}

In this study we assess the seroprevalence of several OIE List A diseases in Central Kazakhstan during the transition to post-Soviet agriculture, and relate our results to changing practices in farming and disease control. Much of Kazakhstan is semi-arid rangeland unsuitable for agriculture, so traditionally Kazakhs are nomadic livestock producers. Soon after independence in 1991, a rapid transition began from a planned to a market economy, which involved the privatisation of state and collective farms. This was accompanied by a collapse in the rural economy, and a concomitant decline in livestock numbers; the number of sheep and goats dropped from 34.2 million in 1993 to 13.7 million in 1996 (Goskomstat 1997). New structures are not yet fully formed, hence state farms and collective farms are still in existence alongside peasant farms and commercial operations (Coulter 1996, Kulekeev 1998, Kerven 2003). 
Traditionally, Kazakhs carried out seasonal migrations with their livestock. Although the Soviet period altered this way of life substantially, seasonal migrations did continue within the structure of the collective and state farms (Robinson \& Milner-Gulland 2003). Veterinary care was highly centralised. Each large-scale collective farm had at least one veterinarian and several animal technicians, and all vaccines and treatments were provided by the state via regional and local veterinary committees. At the time of our study, there was still a veterinarian or animal technician present on all the large enterprises we visited, but many no longer received an income from the state and were providing their services in exchange for food or other goods. Vaccination and routine disease surveillance programmes were still, in theory, running along Soviet lines. However, lack of funds meant that in reality these programmes disintegrated rapidly after independence.

We used a combination of serological investigations and interviews with farmers, government officials and animal health workers. We also collated official statistics on seropreva- lences of monitored diseases and government veterinary policy. By approaching the issue of livestock disease from this range of angles we aimed to obtain a true picture of the status of Kazakhstan's livestock industry with respect to these important diseases, and hence to contribute to policy development in the post-Soviet era. By including tests for diseases which are not officially recognised as present in Kazakhstan, we address potentially undiscovered problems for livestock health in the country.

\section{Materials and methods}

Sample collection

The study was focused on former collective farms, now villages, in Central Kazakhstan (Fig. 1), and took place in 1997-1998. There were 23 ex-collective farms in the region, of which 17 were visited during the study. The villages were sampled along 3 rough transects, the northern one in the steppe, the central one in the boundary between the steppe and semi-desert, and the southern one in the sandy desert. In addition, 3 herds of livestock on the northern transect were sampled. These were using summer

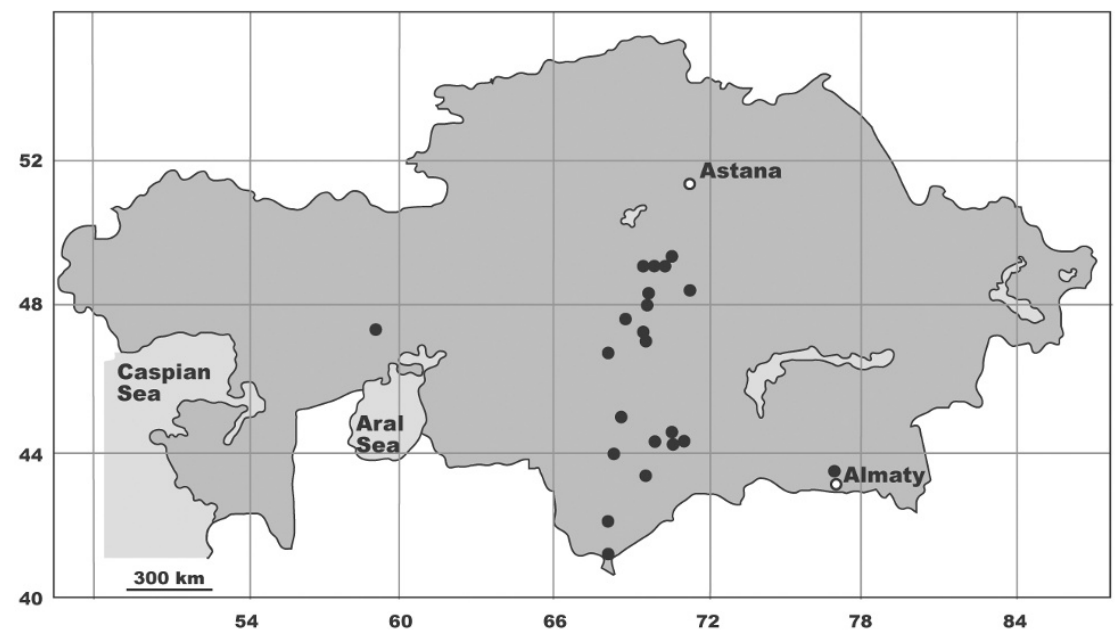

Figure 1. Map of Kazakhstan showing the locations where livestock were sampled. 
grazing areas and had originated in 3 of the sampled villages on the southern transect. One village in the west of the country and 3 in the south-east were also visited. Although the villages were on the site of previous collective farms, and hence the terms farm and village are to some extent interchangeable, we also sampled a number of private farms which had been set up recently in the territory of the former collective farms. Each farm or village can contain several herds.

Farms were selected to provide a representative sample of the conditions under which livestock are kept in Kazakhstan. Due to the large size of the farms, many of them around 80,000 hectares, it was not possible to sample every herd within a farm. Sampling could only occur with the involvement of the local veterinary surgeon or animal technician. However, they were not prepared to carry out random sampling; instead sampling was aimed at ensuring as wide a coverage of parts of the village, ownership and location of the herds as possible. A total of 279 cattle, 542 sheep and 137 goats were sampled. If herds were less than 20 animals, all were sampled. In larger flocks, 20-50 animals were caught for sampling by the owner. There was no pen available to aid in animal selection, but obvious systematic bias (e.g. for animals in good condition) was avoided as far as possible.

Information was collected on the age, breed, vaccination status, geographical location, type of ownership and place of birth of the individual animals that were blood-sampled. A Rose Bengal Plate Test (RBPT) was performed on site, including a negative and positive control to ensure the antigen was intact. Comparison between the results from the RBPT and the equivalent ELISA results from stored samples enabled us to check for sample storage-related problems. Data on the total number of livestock owned by individuals were unreliable, hence only the size of the herd within which the sampled animal was found was used. Supplementary information was obtained from local veterinary surgeons. Government veterinary laboratories provided data for individual villages and for the raion (county) as a whole. Laboratory staff were interviewed about official vaccination programs and serological surveillance for brucellosis operating in the raion.

\section{Sample analysis}

The samples were tested at the World Reference Centre for Foot-and-Mouth Disease (Institute for Animal Health), using the liquid-phase blocking sandwich ELISA (LP-ELISA) for detection of antibodies to FMD virus (FMDV). The LP-ELISA has been validated against the virus neutralisation test (VNT); there is excellent correlation between the 2 assay methods following a monovalent infection (Hamblin et al. 1986). However the LP-ELISA is more serotype-specific than the VNT when testing populations that have been either vaccinated with polyvalent vaccine or infected with multiple serotypes, as may be the case in this population. The samples were tested in duplicate, separately for antibodies to FMDV types A and O. Positive samples were re-tested using the virus neutralisation test (Donaldson et al. 1996, Golding et al. 1976), as well as with an ELISA capable of differentiating between antibodies raised by vaccination and those caused by infection, which is not specific to virus type (Mackay et al. 1998). This validation by a range of assay methods provides not only confirmation of positivity but also differentiation between vaccination and infection.

The samples were also tested at the IAH for antibodies specific to RPV, PPRV, BTV and EHDV using monoclonal antibody based competitive ELISAs (C-ELISA), Anderson \& McKay 1994, Anderson 1984, Thevasagayam et al. 1996). The specificity of C-ELISA rela- 
tive to the agar gel immunodifussion, an OIE prescribed test, is $>99 \%$ for BTV and EHDV (Jeggo et al. 1992, Afshar et al. 1987, 1989, Thervasgayem et al. 1996, Thervasgayem 1998), and neither assay shows any cross reactivity with related orbivirus serogroups. The specificity of the C-ELISA for rinderpest is $>99 \%$ with a sensitivity of $85 \%$ (Geiger et al. 2002).

Samples were tested for antibodies to Brucella spp. at the Veterinary Laboratory Agency using ELISA and the Complement Fixation Test (CFT) according to standard procedures described by Corbel \& Macmillan (1996) and Greiser-Wilke et al. (1991). Measures of predictive value of a positive test and sensitivity are susceptible to many factors, so great caution should be exercised when comparing these parameters from one study with another (Nielsen 2002). However, when the RBPT and ELISA are directly compared, there is close concordance between them (Samartino et al. 1999). In our study, all the ELISA and CFT results were in accord. The RBPT gave a significant proportion of false negatives ( $9 / 23$ of the samples positive in the ELISA/CFT were negative on the RBPT). However there were only 2 cases in which the RBPT was positive but the ELISA and CFT were negative, suggesting that storage problems had not significantly reduced the number of positive results in the ELISA/CFT. The ELISA/CFT results were used in subsequent analyses, given that the RBPT is less sensitive and was performed in field conditions.

\section{Hierarchical modelling of prevalence}

We developed multiple-variable hierarchical generalized linear mixed models that examined the relative contribution of the different levels into which the data are divided to the variation in seroprevalence that we observed. Models could only be developed for FMDV and BTV, for which the antibody prevalences were suffi- ciently high. However, lack of data within the levels of the hierarchy was a problem, making it extremely difficult to estimate the variation between owners within farms. Initially a 3-level (rion, farm, animal) variance components model of sero-status was fitted, using a logistic link. The animal-level variation was modelled under the binomial assumption, with the potential for overdispersion accounted for by fitting an extra-binomial parameter. Single random effect parameters for the raion and farm-level variances were estimated under the assumption of normality. Estimation was by means of Restricted Iterative Generalised Least Squares using a second-order Taylor Expansion and a Penalised Quasi-Likelihood methodology (ML wiN, Multilevel Models Project, Institute of Education, London).

In this intercept-only model for FMDV, the extra-binomial variance parameter was estimated as 1.004, suggesting no binomial overdispersion. Linear contrasts were assessed using approximate Wald-based estimates. There was no significant variation at the raion level $(\mathrm{p}=0.1)$ once the farm- and animal-level variance was accounted for, therefore this level was removed from the model. Every level above farm in the hierarchy was tested in this way for both FMDV and BTV, and all were found not to be significant in a variance components only model. We therefore reduced the model to a 2level model (farm, animal). In this model, the farm-level variance estimate was consistently statistically significant (FMDV: $\mathrm{p}=0.006$; $\mathrm{BTV}$ : $\mathrm{p}=0.003$ ), indicative of clustering of responses by farm. Additional fixed effects identified as important in the univariate analyses (species, origin, age) were then added to this model. Unsurprisingly, the estimate for the farm-level variance decreased in magnitude once these effects had been accounted for, although it was still significant.

Adding a quadratic term for age led to the lin- 
Table 1. Prevalence of antibodies to Brucella and the viruses under study, shown by species.

\begin{tabular}{lccccccc}
\hline Species & $\mathrm{N}$ & FMDV & Brucella & BTV & EHDV & PPRV & RPV \\
\hline Cattle & 2791 & $29.0(81)^{2}$ & $5.4(15)$ & $25.4(71)$ & $2.9(8)$ & $2.2(6)$ & 0 \\
Sheep & 542 & $13.8(75)$ & $1.3(7)$ & $21.4(116)$ & $0.4(2)$ & $0.6(3)$ & 0 \\
Goats & 137 & $5.8(8)$ & $0.7(1)$ & $25.5(35)$ & 0 & $0.7(1)$ & 0 \\
Overall & 958 & $17.1(164)$ & $2.4(23)$ & $23.2(222)$ & $1.0(10)$ & $1.0(10)$ & 0 \\
Cattle/SS & & $* * *$ & $* * *$ & NS & $* *$ & $*$ & - \\
Sheep/goat $^{3}$ & & $*$ & - & NS & - & - & - \\
\hline
\end{tabular}

${ }^{1}$ Sample size, ${ }^{2} \%$ prevalence (number) e.g. 279 cattle were sampled, of which 81 , or $29 \%$, were seropositive to FMDV.

${ }^{3}$ Significance of differences in prevalence between cattle and small livestock (sheep and goats) is shown (cattle/SS) as well as between sheep and goats. Chi-squared tests were carried out for all but EHDV and PPRV, for which Fisher exact tests were used due to small sample sizes. ${ }^{* * *} \mathrm{p}<0.001 ; * * \mathrm{p}<0.01 ; * \mathrm{p}<0.05$; NS $\mathrm{p}>0.05$.

ear component increasing in magnitude and the quadratic effect was significant and negative, indicating that a combination of linear and quadratic age terms might be an acceptable functional form over the range of observation. The same age profile was modelled for each species with differing intercept values, i.e. assuming parallel age:seroprevalence relationships. Age:species interaction terms were included and tested for significance, to assess the parallel lines assumption. However there was no evidence to suggest that, after the difference in intercepts was controlled for, there was any significant difference in the age relationships for any species. The possibility that there could be a significant age profile difference between those animals born on the village and those purchased was also tested for by means of an interaction term, however there was again no significant difference in the age-profiles.

The assumptions of binomial distribution and normality of errors were assessed by consideration of the standardised residuals. The distributional assumptions were met at the farm level. However, at the animal level, there were several high positive residuals, showing that the models over-predicted the number of positive animals. However, from examination of leverage, it was clear there were no values exhibiting undue influences, hence the overall model fit based on analysis of residuals was deemed adequate and the tests of significance for the fixed effects valid.

\section{Results \\ Demographics}

The sample consisted of $86 \%$ (823/958) privately-owned and $14 \%$ collectively-owned livestock, reflecting the ownership situation in Kazakhstan at the time of the survey (Kerven 2003). Most animals were born in the village where they were sampled, but 7\% (71/958) had been bought in. Bought-in animals should in theory have veterinary certificates issued before purchase. Often animals were vaccinated against common diseases during the veterinary examination for certification. Several breeds of livestock were included in the sample, representative of the most frequently encountered breeds in the area. Goat breeds included angora and the local mixed breed, sheep were predominately of the local mixed breed with a few pure-bred individuals (Karakul and Edilbayev), and cattle were relatively evenly distributed between the local mixed breed and 2 pure breeds (Kazakh and Bely Golov).

\section{Prevalence of antibodies}

Table 1 presents the overall prevalence of antibodies, which varied markedly between dis- 
eases and by species. Antibodies were found for all diseases except RP despite the fact that 4 of the diseases have not been assessed or reported previously in Kazakhstan (RP, EHD, PPR, BT). Only 8 of the livestock seropositive for FMDV were positive to the ELISA test for antibodies to non-structural proteins, suggesting that these were the only animals that had been recently exposed to infection with FMDV (Mackay et al. 1998). These animals were all cattle, and were from a village that had experienced an outbreak of FMD a year previously. With the exception of these 8 animals and all animals under 6 months old (138/958 animals, considered most likely to have maternal antibodies), all other positive animals are presumed to have been vaccinated. Only 18 animals were reported to have been vaccinated against FMDV during the previous 2 years. These animals belonged to 2 owners in the same village. Of these, 10 had no detectable antibodies. Of the livestock believed by their owners not to have been vaccinated against FMDV, 17\% (=156/918) had antibodies to FMDV. Only 5 of these had acquired anti- bodies by infection; the other 151 animals are likely to have been vaccinated. These animals were owned by 41 different owners ( $76 \%$ of the owners sampled), indicating widespread ignorance among owners about the vaccination status of their stock.

Of cattle $5.8 \%(=15 / 257)$ and of small ruminants $1.4 \%(=8 / 586)$ thought not to have been vaccinated against brucellosis during the past 2 years were seropositive, which might indicate that they had experienced infection. However, all the livestock (22 cattle and 93 small ruminants) whose owners thought they had been vaccinated recently were seronegative, indicating that they had either not been vaccinated or the vaccine was ineffective. The origin of the animal was a major factor determining the owner's perception of whether it had been vaccinated: $83 \%$ of livestock bought in by their owners were reported as having been vaccinated (none of which had detectable antibodies), in contrast to only $6 \%$ of livestock born in the village.

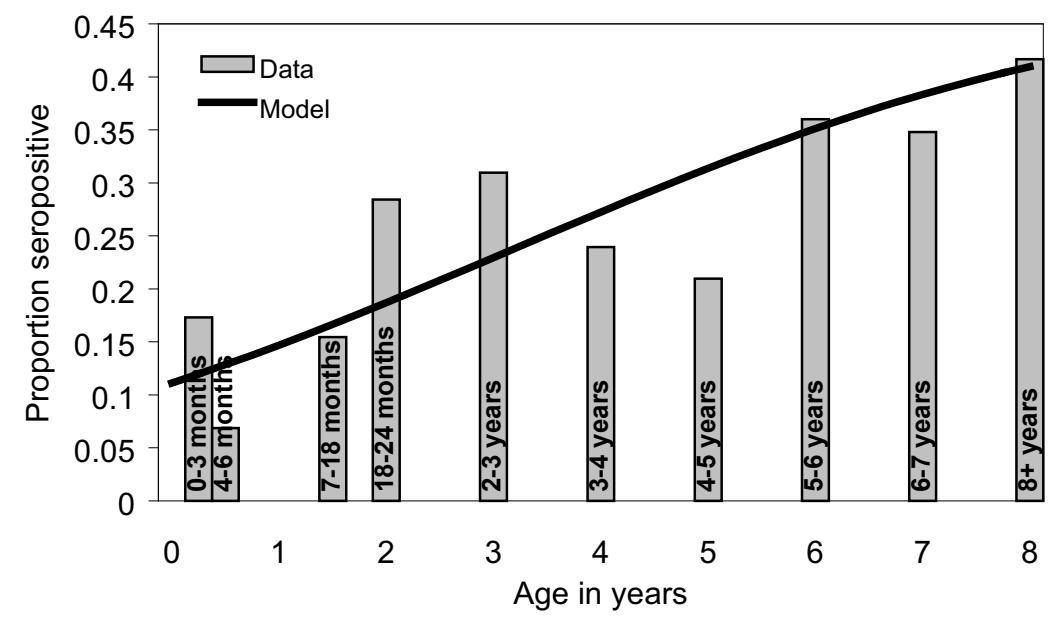

Figure 2. Age-related seroprevalence to bluetongue virus among domestic livestock in Kazakhstan. Raw data $=$, model fit $=\mathbf{-}$. Animals under 6 months old were not included in the model fit, due to the effect of maternal antibodies. There were no significant species differences in the age seroprevalence relationship. 
Table 2. Factors associated with seroprevalence, assessed using simple univariate statistics.

a) Seroprevalence by breed.

\begin{tabular}{|c|c|c|c|c|c|c|c|}
\hline Breed & Species & $\begin{array}{l}\text { Sample } \\
\text { size }\end{array}$ & FMDV & Brucella & BTV & EHDV & PPRV \\
\hline \multirow[t]{4}{*}{ Pure } & Cattle & 163 & 30.7 & 5.5 & 31.3 & 1.2 & 0.6 \\
\hline & Sheep & 107 & 10.3 & - & 42.1 & - & - \\
\hline & Goats & 47 & 4.3 & - & 34 & - & - \\
\hline & Total & 317 & 19.9 & - & 35.3 & - & - \\
\hline \multirow[t]{4}{*}{ Local mix } & Cattle & 116 & 26.7 & 5.2 & 17.2 & 5.2 & 4.3 \\
\hline & Sheep & 435 & 14.7 & - & 16.3 & - & - \\
\hline & Goats & 90 & 6.7 & - & 21.1 & - & - \\
\hline & Total & 641 & 15.8 & - & 17.2 & - & - \\
\hline \multirow[t]{4}{*}{ Chi-squared $^{1}$} & Cattle & & NS & NS & $* *$ & $* *$ & $*$ \\
\hline & Sheep & & NS & - & $* * *$ & - & - \\
\hline & Goats & & NS & - & * & - & - \\
\hline & Total & & NS & - & $* * *$ & - & - \\
\hline
\end{tabular}

${ }^{1}$ Chi-squared tests were used throughout, with the exception of tests for PPRV and EHDV, for which Fisher Exact tests were used due to small sample sizes. $* * * \mathrm{p}<0.001 ;{ }^{* *} \mathrm{p}<0.01 ; * \mathrm{p}<0.05 ; \mathrm{NS} \mathrm{p}>0.05$.

b) Seroprevalence by age.

\begin{tabular}{llcccccc}
\hline Age & Species & $\begin{array}{c}\text { Sample } \\
\text { size }^{2}\end{array}$ & FMDV & Brucella & BTV & EHDV & PPRV \\
\hline Mean age +ve & Cattle & - & 4.5 & 5.9 & 5.1 & 4.4 & 3.6 \\
& Sheep & - & 4 & - & 3.6 & - & - \\
\multirow{5}{*}{ Mean age -ve } & Goats & - & 3 & - & 3.6 & - & - \\
& Cattle & - & 3.7 & 3.8 & 3.5 & 3.9 & 3.9 \\
& Sheep & - & 3.1 & - & 3 & - & - \\
\multirow{2}{*}{ K-W test 1 } & Goats & - & 2.7 & - & 3 & - & - \\
& Cattle & & $* *$ & $* *$ & $* *$ & NS & NS \\
& Sheep & & $* *$ & - & $*$ & - & - \\
& Goats & & NS & - & $*$ & - & - \\
\hline
\end{tabular}

${ }^{1}$ Kruskal-Wallis test

${ }^{2}$ Sample sizes not given because they vary with the disease; they can be found in Table 1 .

The other diseases for which seropositives were found (EHD, PPR, BT) are not vaccinated against, hence antibodies are likely either to be from infection or maternally-derived. There will always be some doubt as to the significance of test results particularly in new geographic areas where little is known about previous exposure and where the prevalence of antibody is low in species that are known to be susceptible.
However, the fact that no antibodies were found to RPV suggests that the RP and PPR ELISA results are specific. There was no overlap between the animals found positive to EHDV and those found positive to PPRV, also suggesting specificity. There was also no clear relationship between the seroprevalences of either PPRV or EHDV and BTV seroprevalence. 
Factors associated with prevalence

Animals bought onto the farm were significantly more likely to test positive for antibodies to FMDV than those born on the farm; this was not the case for the other diseases. Seroprevalence increased significantly with age for FMDV, brucellosis and BTV (Fig. 2, Table 2). There was no significant difference between breeds for FMDV or brucellosis (Table 2). However, for BTV, seroprevalence was significantly lower among cattle and sheep of the "local mixed breed" type than among pure-bred animals. This may be because locally-bred animals are more resistant to disease than purebreds (Daniels et al. 1995). The seropreva- lences to EHDV and PPRV were significantly higher in the local mixed breeds of cattle than in pure-bred cattle. They both gave non-significant results for small stock, due to small sample sizes. However in both cases, the local mixed breeds again had the highest seroprevalences.

\section{Spatial variation in prevalence}

Veterinary policy varies between oblasts (province) and raions; the central veterinary committee in each oblast decides which raions should have vaccination programmes. Official statistics show that about 200,000 cattle were vaccinated against FMD in 1997, all in Dzhambul and South Kazakhstan oblasts, representing

Table 3. Seroprevalence to a) FMDV and b) BTV by oblast.

a)

\begin{tabular}{|c|c|c|c|c|c|}
\hline \multirow[b]{2}{*}{ Oblast } & \multirow[b]{2}{*}{ Location $^{1}$} & \multicolumn{2}{|c|}{ Cattle } & \multicolumn{2}{|c|}{ Small ruminants } \\
\hline & & $\%+\mathrm{ve}$ & $\mathrm{N}$ & $\%+\mathrm{ve}$ & $\mathrm{N}$ \\
\hline Almaty & SE & 50 & 12 & 0 & 8 \\
\hline S. Kazakhstan ${ }^{2}$ & $\mathrm{~S}$ & 52.8 & 36 & 8.9 & 79 \\
\hline Dzhambul $^{2}$ & $\mathrm{~S}$ & 27.8 & 36 & 4.4 & 90 \\
\hline Dzhezkazgan & $\mathrm{C}$ & 27.8 & 151 & 14.4 & 374 \\
\hline Karaganda & $\mathrm{C} / \mathrm{N}$ & 2.9 & 35 & 9.0 & 78 \\
\hline Aktiubinsk & $\mathrm{W}$ & 33.3 & 9 & 22.0 & 50 \\
\hline Overall $^{3}$ & & 29.0 & 279 & 12.2 & 679 \\
\hline
\end{tabular}

${ }^{1}$ The approximate spatial location of the oblast within Kazakhstan is given (see also Fig. 1).

${ }^{2}$ Oblast was the targets of an official FMD vaccination programme.

${ }^{3}$ The overall results for FMDV are not given because there is a significant difference in seroprevalence between species.

b)

\begin{tabular}{|c|c|c|c|c|c|c|c|}
\hline \multirow[b]{2}{*}{ Oblast } & \multirow[b]{2}{*}{ Location } & \multicolumn{2}{|c|}{ Overall } & \multicolumn{2}{|c|}{ Cattle } & \multicolumn{2}{|c|}{ Small ruminants } \\
\hline & & $\%+v e$ & $\mathrm{~N}$ & $\%+v e$ & $\mathrm{~N}$ & $\%+v e$ & $\mathrm{~N}$ \\
\hline Almaty & SE & 5.0 & 20 & 8.3 & 12 & 0 & 8 \\
\hline S. Kazakhstan & $\mathrm{S}$ & 43.5 & 115 & 22.2 & 36 & 53.2 & 79 \\
\hline Dzhambul & $\mathrm{S}$ & 23.0 & 126 & 36.1 & 36 & 17.8 & 90 \\
\hline Dzhezkazgan & $\mathrm{C}$ & 20.2 & 525 & 19.2 & 151 & 20.6 & 374 \\
\hline Karaganda & $\mathrm{C} / \mathrm{N}$ & 24.8 & 113 & 54.3 & 35 & 11.5 & 78 \\
\hline Aktiubinsk & W & 13.6 & 59 & 11.1 & 9 & 14 & 50 \\
\hline Overall & & 23.2 & 958 & 25.4 & 279 & 22.2 & 679 \\
\hline
\end{tabular}


Table 4. A comparison of official data on seroprevalence of brucellosis and the results of this study for 7 raions.

\begin{tabular}{|c|c|c|c|c|c|c|c|c|c|c|c|}
\hline \multirow[b]{3}{*}{ Year } & \multirow[b]{3}{*}{ Raion } & \multicolumn{6}{|c|}{$\%$ seropositive } & \multicolumn{4}{|c|}{ Sample sizes } \\
\hline & & \multicolumn{3}{|c|}{ Cattle } & \multicolumn{3}{|c|}{ Small stock } & \multicolumn{2}{|c|}{ Cattle } & \multicolumn{2}{|c|}{ Small stock } \\
\hline & & Official & This study & $\mathrm{P}^{1}$ & Official & This study & $\mathrm{P}$ & Official & This study & Official & his study \\
\hline 1997 & Suzak & 0 & 0 & - & 0 & 1.4 & NS & 327 & 17 & 94 & 70 \\
\hline 1998 & Moinkum & 0 & - & - & 0.7 & 0 & NS & 160 & 0 & 1203 & 10 \\
\hline 1997 & Sarysu & 0.6 & 0 & NS & $1.1^{2}$ & 1.3 & NS & 2153 & 36 & 2328 & 79 \\
\hline 1997 & Dzhezdin & 1.1 & 0 & NS & - & 0 & - & 5700 & 59 & 0 & 203 \\
\hline 1997 & Zhana-arkin & 0.5 & 8.7 & $* * *$ & 0 & 1.8 & $* *$ & 5400 & 92 & 1000 & 171 \\
\hline 1997 & Nurin & 3.8 & 20 & $* *$ & 1.5 & 1.6 & NS & 21700 & 25 & 3500 & 63 \\
\hline 1998 & Chalkar & 4.1 & 0 & NS & 0 & 0 & - & 556 & 9 & 100 & 50 \\
\hline
\end{tabular}

${ }^{1} \mathrm{P}=$ significance of the Fisher exact test. $* * * \mathrm{p}<0.001, * * \mathrm{p}<0.01$, NS not significant, - test could not be carried out.

${ }^{2}$ The official data are for the same year as the study except in the case of small stock in Sarysu, for which the official data are from 1996.

$39.4 \%$ of these oblasts' cattle population. This study found $40.3 \%$ seroprevalence to FMDV among cattle from these 2 oblasts, which fits well with the official data. There was no official vaccination programme in the other oblasts we surveyed. Nonetheless, we found evidence for similar levels of vaccination in all but Karaganda oblast, which had much lower levels of vaccination (Table 3a). Among smallstock, the proportion seropositive was low, even in the oblasts that had been targetted for vaccination programmes; this is likely to be because official programmes prioritise cattle.

Seropositives to BTV were found in every oblast, indicating that it is widespread throughout Kazakhstan (Table 3b). Antibodies to EHDV and PPRV were only found in Dzhezkazgan oblast, but were found in all 4 villages sampled in the oblast, which suggests that this restricted distribution is not an artefact of sampling procedure.

Official data on brucellosis seroprevalence were obtained for 7 of the 11 raions which we surveyed. Generally, our results conformed well to the official data, however in 2 raions, Zhana-arkin and Nurin, our results were significantly higher than the official statistics (Table
4). It is not possible to tell whether this difference is due to sampling error or whether there is a problem with brucellosis in these raions that has not shown up in the official statistics.

\section{Hierarchical modelling of prevalence}

Parameter estimates for the final, most parsimonious models of prevalence for FMDV and BTV are given in Table 5. In both cases, there was significant clustering at the farm level. For FMDV, sheep were significantly less likely to test positive than cattle, and goats were significantly less likely to test positive than sheep. Animals born on the farm were less likely to test positive than those bought-in. There was a significant linear and quadratic relationship between the probability of a positive test and age, irrespective of species or origin. For BTV, there was no significant effect of species or origin, but only of age.

Thus the multiple-variable hierarchical model confirmed the univariate results with respect to the fixed effects tested. No significant clustering was found at the oblast, raion or village levels, but only at the farm level. However, because the data were limited, with a number of farms only having data collected from one 
Table 5. Parameter estimates for the most parsimonious hierarchical model, with 2 levels (farm, animal).

\begin{tabular}{|c|c|c|c|c|}
\hline \multirow[b]{2}{*}{ Parameter $^{1}$} & \multicolumn{2}{|c|}{ FMDV } & \multicolumn{2}{|c|}{ BTV } \\
\hline & Estimate & SE & Estimate & SE \\
\hline \multicolumn{5}{|l|}{ Random effects } \\
\hline Farm-level variance & 0.372 & 0.173 & 0.779 & 0.255 \\
\hline $\begin{array}{l}\text { Animal-level extra- } \\
\text { binomial variance }\end{array}$ & 0.977 & 0.045 & 0.953 & 0.044 \\
\hline \multicolumn{5}{|l|}{ Fixed effects ${ }^{2}$} \\
\hline Intercept & -0.452 & 0.569 & -2.078 & 0.256 \\
\hline Ovine & -0.816 & 0.217 & - & - \\
\hline Caprine & -1.588 & 0.418 & - & - \\
\hline Origin & -1.474 & 0.537 & - & - \\
\hline Age & 0.276 & 0.085 & 0.334 & 0.080 \\
\hline $\mathrm{Age}^{2}$ & -0.014 & 0.007 & -0.015 & 0.006 \\
\hline
\end{tabular}

${ }^{1}$ All parameters are significant to at least $\mathrm{p}<0.05$, tested using Wald type linear contrasts.

${ }^{2}$ Intercept $=$ mean prevalence among cattle, ovine $=$ difference in mean prevalence between cattle and sheep, caprine $=$ difference in mean prevalence between cattle and goats. Origin = difference in mean prevalence between animals bought in and those born on the village. Age and age 2 cannot be interpreted independently.

owner, it was not possible to distinguish the farm level from the owner level variance.

\section{Animal health and vaccination}

The village veterinary surgeon or animal technician was interviewed whenever possible, allowing comparisons between official policy, reported policy at the village level and the results of the serological survey carried out on these villages. The interviews uncovered wide variation between villages in vaccination policy, and between actual policy at the village level and stated policy at the raion level. In 8 of the 17 villages, vaccination policy had changed since independence because villagers were no longer provided with all vaccines from the state. Privately-owned livestock were rarely vaccinated against any disease except anthrax, because the owner had to pay for vaccination. In 16 of the 17 villages visited, livestock were thought by their owners not to have been vaccinated, yet $16 \%$ (151/940) of supposedly unvaccinated animals had vaccinally-induced antibodies to
FMDV. Thus many veterinary surgeons and livestock owners seemed unaware of the immune status of their animals. In 9 of the villages, serological evidence for brucellosis was found. This was not unexpected, as the villagers were aware that brucellosis was endemic in the area. In 6 of the villages, brucellosis had been diagnosed in humans. Most veterinary surgeons were under the impression that villagers would like to buy vaccines, anthelminthics and antibiotics for their livestock, but could not afford to do so.

\section{Discussion}

For the 2 diseases under official surveillance, FMDV and brucellosis, our results were generally as expected from official data, although we did find 2 raions where brucellosis levels were significantly higher than expected, as well as widespread ignorance about the FMD vaccination status of animals. Currently available serological tests cannot distinguish between Brucella abortus and Brucella melitensis. The most 
likely cause of infection in sheep and goats is $B$. melitensis. However, in cattle either is possible, as $B$. melitensis infection is an emerging problem in Kazakhstan (Amiraeev et al. 1986, Rementsova (pers. comm)). Vaccination against brucellosis does occur in Kazakhstan, but the tests could not distinguish between vaccinated and infected animals. Hence the seroprevalence for brucellosis may reflect either infection or vaccination.

It might be expected that fewer private than collective livestock would be vaccinated against FMD on cost grounds. However our survey found no difference in the proportion of private versus collective-owned animals seropositive to FMDV. This may indicate that some private owners are vaccinating their livestock, or it may reflect the fact that during the privatisation process, collective livestock were distributed among the village workers and thus many privately owned animals were collectively owned 1-2 years before the study. There was no effect of ownership on seroprevalence of the other diseases, which probably reflects similarities in husbandry and the fact that all animals in a village mingle in common grazing areas. The fact that $66 \%$ of bought-in animals had no detectable antibodies to FMDV indicated that either vaccines or certification procedures were ineffective.

Clustering of positive FMDV antibody by oblast might be expected, with higher seroprevalence in Dzhambul and South Kazakhstan oblasts, where there have been ongoing vaccination programs in recent years, or by raion, the level at which vaccination policy is implemented. However, our results suggest vaccination decisions are now being taken by individual owners regardless of regional policies. Further work using a randomised stratified sampling regime would be useful to validate this result, as it could have important policy implications concerning the level at which the government should target vaccination policies. In countries where BTV is known to be present, seroprevalences of $46-52 \%$ in sheep, $44 \%$ in goats and 33-95\% in cattle have been reported (Formenty et al. 1994, Sreenivasulu \& Rao 1999). Our findings of 20-25\% seroprevalence are relatively low, however they suggest that BTV is widespread and endemic in the country (Lundervold et al. 2003). None of the midges (Culicoides spp.) identified as vectors of BTV are known to exist in Kazakhstan, however other Culicoides spp. do exist there. BTV has been reported in some parts of Russia (Vishnyakov et al. 1994) and in raions of China on the other side of the Tien Shan mountains (Hawkes 1995, Regen et al. 1995), but none of the veterinary surgeons that we interviewed believed that the disease existed in Kazakhstan. If BTV is endemic, it may cause only sporadic deaths, which could easily be attributed to other causes.

EHDV and PPRV are also previously unreported in Kazakhstan. Our study found antibodies against these diseases at low prevalence, and only in one oblast in central Kazakhstan. The sample sizes in the other oblasts were lower, hence given the low prevalences of these diseases it may be that they were present in the other areas as well. It is unlikely that the tests were picking up non-specific antibodies given the lack of overlap in seropositivity. Hence it seems that these diseases are present in Kazakhstan, albeit at low levels. Although rinderpest was a problem in Kazakhstan in the pre-Soviet period (Tursunbaev 1973), it has not been reported since 1930, and we found no evidence of its presence in our study.

Our interviews with farmers and officials highlighted the fact that vaccination against diseases of major economic and public health importance is no longer being performed in many parts of rural Kazakhstan, due to lack of funding and a shortage of vaccine. FMD was virtu- 
ally absent from the country from 1985 to 1996 (apart from a few cases in 1987-1990), but since 1996 there have been a number of outbreaks, attributed to poor border controls and a reduction in vaccine coverage. Increases in epidemic disease may constitute a serious problem for Kazakhstan's rural economy in future, and the situation is likely to worsen in the next few years as the proportion of unvaccinated livestock increases. Hence there is a need to act now to strengthen veterinary services in rural areas.

\section{Acknowledgements}

We are very grateful to the many people who have helped us with this work. We thank INTAS (projects KZ-95-29 and KZ-96-2056) and the BBSRC for financial support. Particular thanks go to Sarah Robinson, Sinead Oates, Eric Morgan and Roz Shreeves who were involved in collecting the data we analysed here. We are very grateful to the staff of the Institute for Animal Health, particularly John Anderson, Paul Kitching, David Mackay, and Paul Davies, and the Veterinary Laboratory Agency, particularly Lorraine Perrett, for their help with sample analysis. We would also like to thank the staff of the Kazakh Scientific Veterinary Research Institute, particularly Aidar Namet, N.P. Ivanov, S. Baramova, Zh.O. Omirzhanov. We thank Graham Medley very much for his help and advice, Kamilla Magzieva for her help with sample transportation, and Steven Archibald for help in producing the map.

\section{References}

Afshar A, Thomas FC, Wright PF, Shapiro JL, Shettigara PT, Anderson J: Comparison of competitive and indirect enzyme-linked immunosorbent assays for detection of bluetongue virus antibodies in serum and whole blood. J. Clinical Microbiol 1987, 25, 1705-1710.

Afshar A, Thomas FC, Wright PF, Shapiro JL, Anderson J: Comparison of competitive C ELISA, indirect ELISA and standard AGID tests for detection of bluetongue virus antibodies in cattle and sheep. Vet Rec 1989, 124, 136- 141.

Amiraeev SA, Sattarov AI, Ivanov NP: Epidemiologiya i epizootologiya brutselleza [The epidemiology and epizootology of brucellosis]. 1986 Nauka, Almaty, Kazakhstan.
Anderson J: Use of Monoclonal Antibody in a Blocking ELISA to Detect Group Specific Antibodies to Bluetongue Virus. J. Immunological Methods 1984, 74, 139-149.

Anderson J, McKay JA: The detection of antibodies against peste des petites ruminants virus in cattle, sheep and goats and the possible implications to rinderpest control programmes. Epidemiology and Infection 1994, 112, 225-231.

Anonymous: Goskomstat Statisticheskii sbornik [The Statistical Bulletin]. Goskomstat [Agency of the Republic of Kazakhstan on Statistics], Almaty, Kazakhstan. 1997.

Anonymous: MLC Feeding the Ewe. Meat and Livestock Commission, Milton Keynes, UK. 1983.

Corbel MJ, Macmillan AP: OIE Manual of Standards for Diagnostic Tests and Vaccines. 1996.

Coulter HK: An overview of the agricultural sector. Kazakhstan: Agricultural Management and Marketing Information System and Pilot Wholesale Market FDKAZ 9501. TACIS, EU, Brussels, Belgium. 1996.

Daniels PW, Sendow I, Melville LF: Epidemiological Considerations in the Study of Bluetongue viruses. Bluetongue Disease in south east Asia and the Pacific, Proceedings of the First south east Asia and the Pacific Regional Bluetongue Symposium 1995, 110-119.

Donaldson AI, Barnett P, Kitching RP: Foot-andmouth Disease. In: OIE Manual of Standards for Diagnostic Tests and Vaccines, OIE, Rue De Prony, Paris, pp. 47-56. 1996.

Formenty P, Domenech J, L'Auginie F, Ouattara M, Diawara S, Raath JP, Grobler D, Leforban Y, Angba A: Epidemiologic survey of bluetongue virus in sheep, cattle and various species of wildlife in Cote-d'Ivoire. Revue Scientifique et Technique de l'Office International des Epizooties 1994, 13, 737-751.

Geiger R, Wamway H, Ndungu E: Preliminary results of the validation and comparison of ELISAs for the surveillance of antibodies to rinderpest virus in cattle and livestock. FAO EMPRES Livestock Programme: maintaining momentum and commitment; Technical Consultation on the Global Rinderpest Eradication Programme (GREP), 30th September- 2nd October 2002, Italy Rome. Rome: FAO pp. 45-58. 2002

Golding SM, Hedger RS, Talbot P: Radial immunodiffusion and serum-neutralisation techniques for the assay of antibodies to swine vesicular disease. Res. Vet. Sc. 1976, 20, 142-147. 
Greiser-Wilke I, Macmillan AP, Moennig V: A competition ELISA with monoclonal antibodies for the analysis of sera from cattle of 2 herds with suspected brucellosis. Tierarztliche-Praxis 1991, 19, 131-134.

Hamblin C, Barnett ITR, Crowther JR: A new enzyme-linked immunosorbent assay (ELISA) for the detection of antibodies against foot-andmouth disease virus. II Application. Journal of Immunological Methods 1986, 93, 123-129.

Hawkes A: The Global Distribution of Bluetongue. Bluetongue Disease in Southeast Asia and the Pacific, Proceedings of the First Southeast Asia and the Pacific Regional Bluetongue Symposium, Kunming, China, 22-24 August 1995. Australian Centre for International Agricultural Research Proceedings 66. ACIAR proceedings 1995, 66, 6-14.

Jeggo M, Wright P, Anderson J, Eaton B, Afshar A, Pearson J, Kirkland P, Ozawa Y: Review of the IAEA meeting in Vienna on standardisation of the competitive ELISA test and reagents for the diagnosis of bluetongue. Bluetongue, African horse sickness and related orbiviruses, Preceedings of the Second International Symposium (T.E. Walton and B.I. Osburn Eds), CRC Press, Boca Raton, 1992, pp. 547-560.

Kerven $C$ : Prospects for pastoralists in Kazakhstan and Turkmenistan: From State Farms to Private Flocks.. Routledge Curzon Press, London. 2003.

Kulekeev ZA: Statistical Bulletin [Statisticheskii cbornik]. Agency of the Republic of Kazakhstan on Statistics, Almaty, Kazakhstan. 1998.

Lundervold $M$ : Infectious diseases of saiga antelopes and domestic livestock in Kazakhstan. PhD thesis, University of Warwick, UK. 2001.

Lundervold M, Milner-Gulland EJ, O'Callaghan CJ, Hamblin C: First evidence of bluetongue virus in Kazakhstan. Vet. Microbiol. 2003, 92, 281-292.

Nielsen K: Diagnosis of brucellosis by serology. Vet. Microbiol. 2002, 90, 447-54.

Regen M, Fulai A, Qin S, Xinli Z: Serological Survey of Bluetongue in Sheep and Cattle in Inner Mongolia. Proceedings of the First South East Asia and Pacific Regional Bluetongue Symposium, Kunming, China. Australian Centre for International Agricultural Research Proceedings 66. 1995.

Robinson S, Milner-Gulland EJ: Political change and factors limiting numbers of wild and domestic ungulates in Kazakhstan. Human Ecology 2003, 31, 87-110.
Samartino L, Gall D, Gregoret R, Nielsen K: Validation of enzyme-linked immunosorbent assays for the diagnosis of bovine brucellosis. Veterinary Microbiology 1999, 70, 193-200.

Sreenivasulu D, Rao MVS: Seroepidemiology of bluetongue disease in Andhra Pradesh, India. Indian Journal of Animal Sciences 1999, 69, 292294.

Thevasagayam JA, Wellby MP, Mertens PPC, Burroughs $J N$, Anderson $J$ : Monoclonal antibody based competitive ELISA for the detection of antibodies against epizootic haemorrhagic disease of deer virus. J. Virol. Methods 1996, 57, $117-$ 126.

Thevasagayem JA: The Epizootic Hemorrhagic Disease Virus Serogroup. PhD Thesis, University of Hertfordshire. 1998.

Tursunbaev A: Settlement of the nomads and seminomads of Central Asia and Kazakhstan. In: Essays on the Agricultural History of the Peoples of Central Asia and Kazakhstan. Nauka, Leningrad, USSR, 1973, pp. 223-234.

Vishnyakov I, Strigakov A, Novikova M, Lunitsin A: Bluetongue in Russia: virus identification and investigation with monoclonal antibodies. The AllRussian Research Institute of Veterinary Virology and Microbiology, Pokrov, Russia. 1994.

Webster J: Understanding the dairy cow. 2nd Ed. Blackwell Scientific, Oxford, UK. 1993.

\section{Sammanfattning}

En serologisk studie av husdyr i Kazakhstan i etterSoviet tidens overganger innen husdyrbruk og sykdoms kontrol.

Resultater fra en serologisk studie av husdyr i Kazakhstan i perioden 1997-1998 blir presentert. Serum fra 958 dyr (storfe, sau og geit) ble analysert for antistoffer mot munn- og klovsyke (foot and mouth disease, FMD), blåtunge (BT), epizootic haemorrhagic disease (EHD), rinderpest (RP), peste des petits ruminants (PPR) og mot Brucella spp. Vaksinasjonsstatusen til husdyra ble også undersøkt og relatert til endringer $\mathrm{i}$ veterinærrutiner som har skjedd siden Kazakhstan ble uavhengig i 1991. For de to sykdommene under offisiell tilsyn (FMD of brucellose), var resultatene våre $\mathrm{i}$ overensstemmelse med offisielle tall, men vi fant signifikant høyere hyppighet av brucellose i 2 distrikter, og mange bønder visste ikke om dyra var vaksinerte mot FMD. Totalt $23 \%$ av dyra hadde antistoffer mot BT virus, og sero- 
positive dyr ble funnet i mange områder. Dette tydet på mulige endemiske forhold, selv om dette ikke tidligere er rapportert. Vi fant også noen få seropositive dyr mot EHD og PPR virus. Det er derfor mulig at disse sykdommene finnes i Kazakhstan. En hierar- kisk model viste at dyr med antistoffer mot FMD og Brucella spp. samlet seg på lokalt (gård/landsby) nivå, heller enn på større (område) nivå. Dette var uventet for FMD, siden vaksinasjon mot FMD varierer mellom ulike områder innenfor Kazakhstan.

(Received September 1, 2004; accepted November 30, 2004).

Reprints may be obtained from: E.J. Milner-Gulland, Department of Environmental Science and Technology, Imperial College, Exhibition Road, London, SW7 2AZ, UK. E-mail: e.j.milner-gulland@imperial.ac.uk, tel: (+44) 0207594 2509, fax: (+44) 02095942308. 